\title{
HUBUNGAN STATUS EKONOMI KELUARGA DENGAN PERILAKU PENGOBATAN SENDIRI (SELF-MEDICATION)
}

\author{
Dewi Utari ${ }^{1}$, Wiwing Setiono ${ }^{1}$ \\ ${ }^{1}$ Program Studi Ilmu Keperawatan, Stikes Jenderal Achmad Yani Yogyakarta \\ E-mail: dewiutari_04@yahoo.com
}

\begin{abstract}
Background: Health degree is an important component of health development. One of the indicators is morbidity rate. Based on National Health Survey in 2008, the number of morbidity rate is $33.24 \%$ where $65.59 \%$ of population applied self-medication to treat their health problems. Many factors influence people to use self-medication. Family economic status is suspected to be one of them.

Objective: This study aimed to identify the correlation between family economic status and self-medication behavior.

Methods: A quantitative cross sectional design study with retrospective approach was applied. Cluster random sampling technique was employed to 71 respondents. The Kendall Tau test was performed to analyze the data. The probability risk factors of self-medication was identified using odds ratio.

Results: The family economic status were gained with $81.7 \%$ in high category and $15.5 \%$ in low category. The result of self-medication behavior showed $69 \%$ of the respondents often did self-medication, $15.5 \%$ rarely, and $15.5 \%$ never. The Kendall Tau correlation was $0,515(\mathrm{p}<0.05)$ and the odds ratio was 8,941.

Conclusion: There is a moderate correlation between family economic status and self-medication behavior where the family with high economic status is more likely implement self-medication 8,941 times more than the one with low economic status.
\end{abstract}

Keywords: Economic Status, Family, Behavior, Self-Medication

\section{PENDAHULUAN}

Pembangunan kesehatan merupakan bagian yang tidak terpisahkan dari pembangunan manusia yang diupayakan oleh pemerintah. Tujuan dari pembangunan kesehatan yaitu untuk meningkatkan kesadaran, kemauan, dan kemampuan hidup sehat bagi setiap orang. Hal ini dimaksudkan agar terwujud derajat kesehatan yang setinggi-tingginya. ${ }^{1}$ Salah satu indikator yang digunakan untuk menentukan derajat kesehatan penduduk adalah angka kesakitan atau morbiditas. Persentase penduduk yang memunyai keluhan kesehatan secara nasional pada tahun 2008 adalah 33,24\%. ${ }^{2}$

Seseorang yang mengalami sakit akan berupaya mencari sumber pengobatan untuk mengatasi sakitnya, yaitu pengobatan rumah tangga atau pengobatan sendiri, pengobatan medis, dan pengobatan tradisional. ${ }^{3}$ Tindakan pertama yang paling banyak dilakukan dalam upaya pengobatan sakit adalah pengobatan sendiri (selfmedication). ${ }^{4} \quad$ Pengobatan sendiri dalam pengertian umum adalah upaya yang dilakukan untuk mengobati diri sendiri menggunakan obat bebas, obat tradisional, atau cara lain tanpa nasihat tenaga kesehatan. ${ }^{5}$ Pengobatan sendiri dalam hal ini dibatasi hanya untuk obat modern dan obat tradisional.

Masyarakat memilih pengobatan sendiri karena sakit ringan, hemat biaya, dan hemat waktu, serta sifatnya sementara, yaitu 
penanggulangan pertama sebelum berobat ke puskesmas atau mantri. ${ }^{5}$ Data Susenas 2008, menunjukkan bahwa sebesar $65,59 \%$ penduduk yang memiliki keluhan kesehatan memilih untuk mengobati sendiri. Sebesar $72,21 \%$ dari angka tersebut menggunakan obat modern, 22,26\% menggunakan obat tradisional, dan 5,53\% menggunakan obat jenis lainnya. Data di provinsi Daerah Istimewa Yogyakarta menunjukkan sebesar $57,14 \%$ penduduknya mengobati sendiri dengan rincian $58,52 \%$ dari jumlah tersebut berdomisili di daerah perkotaan dan $41,48 \%$ di pedesaan". Ada beberapa faktor yang memengaruhi masyarakat dalam melakukan pengobatan sendiri. Faktor-faktor yang memengaruhi seseorang melakukan pengobatan sendiri yaitu umur, jenis kelamin, pendidikan, status ekonomi, tempat tingal, dan jenis penyakit/keluhan. ${ }^{6}$ Perilaku pengobatan sendiri diakibatkan oleh beberapa faktor yaitu, status ekonomi keluarga, gaya hidup, kemudahan memperoleh produk obat, pengobatan penyakit, dan faktor lingkungan, ketersediaan produk baru, faktor demografi dan epidemiologi, perbaikan pada sektor kesehatan. $^{7}$

Tinggi rendahnya status ekonomi keluarga memengaruhi perilaku pengobatan sendiri. Keluarga dengan status ekonomi tinggi lebih banyak melakukan pengobatan sendiri dibandingkan keluarga dengan status ekonomi rendah. Selain itu keluarga dengan status ekonomi tinggi juga cenderung membeli obat lebih dari yang seharusnya dibutuhkan/penggunaan obat tanpa indikasi. ${ }^{8}$ Selain itu orang dengan status ekonomi tinggi lebih banyak membeli, menyimpan, menggunakan obat. ${ }^{6}$ Namun, tingkat ekonomi penduduk tidak berhubungan bermakna dengan menggunakan obat tradisional dalam pengobatan sendiri. ${ }^{9}$

Status ekonomi adalah sebuah komponen kelas sosial yang mengacu pada tingkat pendapatan dan sumber pendapatan keluarga. Faktor-faktor yang memengaruhi status ekonomi seseorang meliputi pendidikan, pekerjaan, latar belakang budaya, dan pendapatan. ${ }^{10}$

Hasil studi pendahuluan yang dilakukan di lokasi penelitian, melalui metode wawancara pada tokoh masyarakat mendapatkan hasil bahwa masih banyak di antara penduduk yang melakukan pengobatan sendiri (self-medication) untuk mngatasi sakit yang dialaminya. Sebagian besar penduduk bekerja sebagai karyawan swasta dan Pegawai Negeri Sipil (PNS), sedangkan yang lain bekerja sebagai petani, buruh, pedagang, dan wiraswasta. Secara umum penelitian ini bertujuan untuk mengetahui hubungan antara status ekonomi keluarga dengan perilaku pengobatan sendiri di Dusun Madugondo, Sitimulyo, Piyungan, Bantul DIY. Tujuan lain dalam penelitian ini adalah mengetahui peluang faktor risiko status ekonomi keluarga terhadap penggunaan jenis obat dalam pengobatan sendiri. 


\section{BAHAN DAN CARA PENELITIAN}

Penelitian ini meruapakan penelitian kuantitatif dengan studi korelasional. Desain penelitian yang digunakan adalah cross sectional dengan pendekatan retrospektif. Proses pelaksanaan penelitian yaitu menggunakan metode survei.

Status ekonomi keluarga dikategorikan menjadi status ekonomi tinggi dan rendah. Perilaku pengobatan sendiri dalam penelitian ini diartikan sebagai praktik yang dilakuan oleh anggota keluarga untuk mengobati diri sendiri menggunakan obat modern dan obat tradisional tanpa indikasi dari tenaga kesehatan. Perilaku pengobatan sendiri dikategorikan menjadi tidak pernah, jarang, dan sering.

Populasi dalam penelitian ini adalah seluruh keluarga yang bertempat tinggal di Dusun Madugondo yang berjumlah 208 Kepala Keluarga (KK) dan tersebar di 4 Rukun Tetangga (RT). Sampel diambil menggunakan kriteria inklusi dan eksklusi dan berdasarkan teknik cluster random sampling. Alat ukur yang digunakan dalam penelitian ini adalah kuesioner yang telah diuji validitas dan reliabilitasnya. Kuesioner terdiri atas beberapa kelompok pertanyaan yaitu, identitas responden, data variabel status ekonomi keluarga, dan data variabel pengobatan sendiri.

Data yang terkumpul diuji menggunakan uji statistik deskriptif untuk mendapatkan gambaran distribusi frekuensi karakteristik demografi responden, sedangkan analisis bivariat dilihat dengan uji Kendal Tau dengan tingkat kepercayaan 95\% untuk mengetahui adanya hubungan antarvariabel. Selain itu, untuk mengetahui peluang faktor risiko status ekonomi keluarga terhadap penggunaan jenis obat dalam pengobatan sendiri diuji dengan menggunakan analisis odds ratio.

\section{HASIL DAN PEMBAHASAN}

\section{Karakteristik responden di Dusun}

Madugondo, Sitimulyo, Piyungan, Bantul

Hasil penelitian terhadap keluarga yang bertempat tinggal di Dusun Madugondo, Sitimulyo, Piyungan, Bantul diperoleh karakteristik responden seperti terlihat di tabel 1.

\begin{tabular}{|c|c|c|}
\hline Karakteristik & $f$ & $\%$ \\
\hline \multicolumn{3}{|l|}{ Umur } \\
\hline $\begin{array}{l}<55 \text { tahun } \\
\geq 55 \text { tahun }\end{array}$ & $\begin{array}{l}59 \\
12 \\
\end{array}$ & $\begin{array}{l}83.1 \\
16.9 \\
\end{array}$ \\
\hline \multicolumn{3}{|l|}{ Jenis Kelamin } \\
\hline Laki-laki & 29 & 40.8 \\
\hline Perempuan & 42 & 59.2 \\
\hline \multicolumn{3}{|l|}{ Pendidikan } \\
\hline Tidak Sekolah & 5 & 7.0 \\
\hline SD & 5 & 7.0 \\
\hline SMP & 12 & 16.9 \\
\hline SMA & 32 & 45.1 \\
\hline PT & 17 & 23.9 \\
\hline \multicolumn{3}{|l|}{ Pekerjaan } \\
\hline Tidak Bekerja & 20 & 28.2 \\
\hline Buruh & 8 & 11.3 \\
\hline Wiraswasta & 5 & 7.0 \\
\hline Petani & 4 & 5.6 \\
\hline Karyawan & 12 & 16.9 \\
\hline Swasta & 14 & 19.7 \\
\hline $\begin{array}{l}\text { PNS/TNI/Polri } \\
\text { Lainnya }\end{array}$ & 8 & 11.3 \\
\hline Jumlah & 71 & 100 \\
\hline
\end{tabular}

Sebagian besar responden adalah berumur $<$ 55 tahun (83.1\%), berjenis kelamin 
perempuan (59.2\%), berpendidikan SMA (45.1\%), dan tidak bekerja (28.2\%).

Status ekonomi keluarga di Dusun Madugondo, Sitimulyo, Piyungan, Bantul

Hasil penelitian terhadap status ekonomi keluarga di Dusun Madugondo, Sitimulyo, Piyungan, Bantul disajikan pada tabel 2.

Tabel 2 Distribusi Frekuensi Status Ekonomi Keluarga Responden

\begin{tabular}{lll}
\hline Status & $\mathbf{f}$ & $\%$ \\
Ekonomi & & \\
\hline Tinggi & 58 & 81.7 \\
Rendah & 13 & 18.3 \\
\hline Jumlah & $\mathbf{7 1}$ & $\mathbf{1 0 0}$ \\
\hline
\end{tabular}

Tabel 2 menunjukkan bahwa mayoritas responden memiliki status ekonomi keluarga yang tinggi yaitu sebanyak 58 orang (81.7\%) dari total 71 responden dalam penelitian ini.

Perilaku pengobatan sendiri di Dusun Madugondo, Sitimulyo, Piyungan, Bantul

Hasil penelitian terhadap perilaku pengobatan sendiri di Dusun Madugondo, Sitimulyo, Piyungan, Bantul dapat dilihat pada tabel 3, sedangkan distribusi frekuensi jenis obat yang digunakan oleh responden dalam pengobatan sendiri disajikan dalam tabel 4 .

Tabel 3 Distribusi Frekuensi Responen Berdasarkan Perilaku Pengobatan Sendiri

\begin{tabular}{lll}
\hline Perilaku Pengobatan Sendiri & $\mathbf{f}$ & $\%$ \\
\hline Sering Melakukan & 49 & 69.0 \\
Jarang Melakukan & 11 & 15.5 \\
Tidak Pernah Melakukan & 11 & 15.5 \\
\hline Jumlah & $\mathbf{7 1}$ & $\mathbf{1 0 0}$ \\
\hline Tabel 3 menunjukkan sebagian besar \\
responden sering melakukan tindakan \\
pengobatan sendiri sebanyak 49 orang \\
(69\%), sedangkan yang jarang dan tidak
\end{tabular}

pernah melakukan masing-masing sebesar 11 orang (15.5\%).

Tabel 4 Distribusi Frekuensi Responden Berdasarkan Jenis Obat yang dibunakan dalam Perilaku Pengobatan Sendiri

\begin{tabular}{lll}
\hline Jenis Obat yang Digunakan & $\mathbf{f}$ & $\%$ \\
\hline Obat Modern & 39 & 54.9 \\
Obat Tradisional & 21 & 29.6 \\
Lainnya & 11 & 15.5 \\
\hline Jumlah & $\mathbf{7 1}$ & $\mathbf{1 0 0}$ \\
\hline Karakteristik responden & berdasarkan jenis \\
obat yang digunakan & dalam & pengobatan
\end{tabular}
sendiri yang paling banyak adalah menggunakan obat modern yaitu sebanyak 39 orang $(54.9 \%)$.

Hubungan status ekonomi keluarga dengan perilaku pengobatan sendiri di Dusun Madugondo, Sitimulyo, Piyungan, Bantul

Tabulasi silang dan hasil uji statistik hubungan status ekonomi keluarga dengan perilaku pengobatan sendiri di Dusun Madugondo, Sitimulyo, Piyungan, Bantul dapat diamati pada tabel 5 .

Tabel 5 Tabulasi silang dan hasil uji statistik hubungan status ekonomi keluarga dengan perilaku pengobatan sendiri.

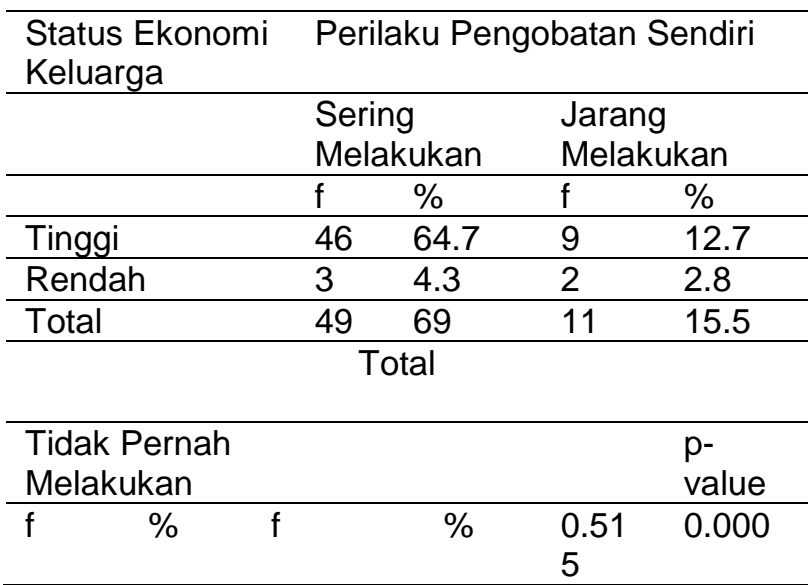




\begin{tabular}{llll}
\hline 3 & 4.2 & 15 & 81.6 \\
\hline 8 & 11.3 & 38 & 18.4 \\
\hline 11 & 15.5 & 71 & 100 \\
\hline
\end{tabular}

Tabel 5 menunjukkan keluarga yang memiliki status ekonomi tinggi sering melakukan pengobatan sendiri sebanyak 46 orang $(64.7 \%)$. Sedangkan keluarga dengan status ekonomi rendah tidak pernah melakukan pengobatan sendiri sebanyak 8 orang (11.3\%). Hasil perhitungan statistik menggunakan uji Kendall Tau diperoleh $p$ value sebesar $0.000<\alpha(0.05)$. Hal ini memperlihatkan bahwa ada hubungan yang signifikan antara status ekonomi keluarga dengan perilaku pengobatan sendiri (selfmedication). Nilai koefisien $(\tau)$ yang positif menunjukkan semakin tinggi status ekonomi keluarga maka, perilaku pengobatan sendiri akan semakin sering. Nilai koefisien korelasi sebesar 0.515 menjelaskan tingkat hubungan antara status ekonomi keluarga dengan perilaku pengobatan sendiri berada pada level sedang.

Banyaknya responden yang memiliki status ekonomi keluarga kategori tinggi diprediksikan akan lebih banyak melakukan pengobatan sendiri. Hal ini sesuai dengan teori dari Friedman, ${ }^{10}$ bahwa keluarga yang memunyai status ekonomi atau pendapatan tinggi akan memraktikkan gaya hidup yang mewah dan lebih komsumtif karena mereka mampu untuk membeli semua yang dibutuhkan bila dibandingkan dengan keluarga berada pada tingkat ekonomi yang rendah. Dalam hal ini termasuk penggunaan obat untuk tindakan pengobatan sendiri.

Semakin meningkatnya status ekonomi keluarga diasumsikan semakin meningkat juga pemberdayaan masyarakat, sehingga tingkat pendidikan pun meningkat. Semakin tinggi tingkat pendidikan maka semakin mudah akses untuk mendapatkan informasi. Selain itu, hal ini juga dikombinasikan dengan tingkat ketertarikan individu terhadap masalah kesehatan, partisipasi langsung masyarakat terhadap pengambilan keputusan dalam masalah kesehatan meningkat. Sehingga keluarga dengan status ekonomi tinggi lebih banyak melakukan pengobatan sendiri dibandingkan keluarga dengan status ekonomi rendah. ${ }^{7} \mathrm{Hal}$ ini sesuai dengan penelitian Supardi dan Raharni ${ }^{6}$ serta Pusvita $^{8}$, yang menunjukkan bahwa salah satu faktor yang memengaruhi perilaku pengobatan sendiri (selfmedication) adalah status ekonomi. Penelitian ini juga didukung penelitian yang dilakukan oleh Supardi ${ }^{4}$, yang menyatakan pengobatan sendiri merupakan bagian dari sosial ekonomi masyarakat, di mana pengobatan sendiri lebih banyak dilakukan oleh kelas sosial ekonomi yang lebih tinggi. Kristina dkk ${ }^{11}$ juga menyampaikan bahwa ada hubungan yang signifikan antara jumlah pendapatan dengan perilaku pengobatan sendiri. Namun, hasil penelitian ini bertentangan dengan penelitian yang dilakukan oleh Supardi $\mathrm{dkk}^{12}$ yang 
menunjukkan bahwa tingkat ekonomi penduduk tidak berhubungan bermakna dengan penggunaan OT (obat tradisional).

\section{Proporsi status ekonomi keluarga dengan jenis obat dalam pengobatan sendiri}

Setelah diketahui hubungan variabel status ekonomi keluarga dengan perilaku pengobatan sendiri (self-medication), selanjutnya dilakukan perbandingan proporsi antara status ekonomi keluarga dengan jenis obat yang digunakan dalam pengobatan sendiri menggunakan analisis odds ratio.

Tabel 6 Perhitungan Odds Ratio Penggunaan Obat dalam Pengobatan Sendiri

\begin{tabular}{lllll}
\hline $\begin{array}{l}\text { Status } \\
\text { Ekonomi }\end{array}$ & \multicolumn{2}{l}{$\begin{array}{l}\text { Jenis } \\
\text { dalam } \text { Obat yengobatan Sendiri }\end{array}$} & $\begin{array}{l}\text { Digunakan } \\
\text { Im }\end{array}$ \\
\cline { 2 - 5 } & Modern & Tradisional & Lainnya & \\
\hline Tinggi & $38(\mathrm{a})$ & $17(\mathrm{c})$ & 3 & 58 \\
Rendah & $1(\mathrm{~b})$ & $4(\mathrm{~d})$ & 8 & 13 \\
\hline Jumlah & 39 & 21 & 11 & 71 \\
\hline
\end{tabular}

Nilai odds ratio dihitung sebagai berikut:

$\psi(p s i)=(a / c) /(b / d)=a d / b c=38 \times 4 / 1 \times 17=8.941$

Berdasarkan perhitungan di atas maka nilai odds ratio sebesar 8.941 . Hal ini berarti bahwa keluarga dengan status ekonomi tinggi 8.941 kali lebih sering menggunakan obat modern daripada keluarga dengan status ekonomi rendah dalam melakukan pengobatan sendiri.

Keluarga dengan status ekonomi tinggi diasumsikan mempunyai pendidikan yang tinggi juga sehingga mereka lebih percaya pada pemikiran-pemikiran yang rasional dan objektif, yaitu apabila sakit maka mengonsumsi obat modern yang sudah teruji secara pre klinis maupun klinis ${ }^{7}$. Selain itu, keluarga dengan status ekonomi tinggi lebih mudah dan sering mengakses informasi dengan menggunakan alat modern seperti jaringan internet, televisi, dan sumbersumber informasi lain yang umumnya lebih banyak menampilkan infomasi obat-obat modern. Hal ini memicu keluarga ekonomi tinggi lebih sering menggunakan obat modern dibandingkan dengan obat tradisional. Sejalan dengan penelitian Supardi $\mathrm{dkk}^{12}$, bahwa persentase terbesar masyarakat mendapat informasi tentang obat (modern) yaitu dari televisi.

\section{KESIMPULAN}

Berdasarkan hasil penelitian, analisis data, dan pembahasan maka, dapat disimpulkan sebagai berikut:

1. Status ekonomi keluarga di Dusun Madugondo, Sitimulyo, Piyungan, Bantul mayoritas masuk dalam kategori tinggi (81.7\%).

2. Perilaku pengobatan sendiri (selfmedication) di Dusun Madugondo, Sitimulyo, Piyungan, Bantul sebagian besar adalah sering melakukan pengobatan sendiri (69\%).

3. Ada hubungan yang signifikan antara status ekonomi keluarga dengan perilaku pengobatan sendiri (self-medication) di Dusun Madugondo, Sitimulyo, Piyungan, Bantul DIY ( $p$-value $=0.000)$ dengan tingkat keeratan yang sedang $(\tau=0.515)$. 
4. Keluarga dengan status ekonomi yang tinggi cenderung 8.941 lebih sering menggunakan obat modern daripada keluarga dengan status ekonomi rendan dalam melakukan pengobatan sendiri (self-medication).

\section{KEPUSTAKAAN}

1. Profil kesehatan Indonesia 2008 [Internet]. Departemen Kesehatan Republik Indonesia. 2009. Available from: http://www.depkes.go.id/.

2. Profil kesehatan Indonesia 2009 [Internet]. Kementerian Kesehatan Republik Indonesia. 2009. Available from: http://www.depkes.go.id/.

3. Zulkifli. Obat itu racun: panduan penting memilih dan waspada obat: Grha Pustaka; 2009.

4. Supardi S. Pengobatan sendiri di masyarakat dan masalahnya. Cermin Dunia Kedokteran. 1997;118:48-50.

5. Supardi S, Notosiswoyo $M$. Pengobatan sendiri sakit kepala, demam, batuk dan pilek pada masyarakat di Desa Ciwalen, Kecamatan Warungkondang, Kabupaten Cianjur, Jawa Barat. Majalah IImu Kefarmasian. 2005;2(3):134-44.

6. Supardi S, Raharni. Penggunaan obat yang sesuai dengan aturan dalam pengobatan sendiri keluhan demam, sakit kepala, batuk dan flu (hasil analisis lanjut data survey kesehatan rumah tangga (SKRT) 2001). Jurnal Kedokteran YARSI. 2006;14(1):67-9.

7. The story of self-care and selfmedication; 40 years of progress, 1970-2010. [Internet]. World SelfMedication Industry. 2010. Available from: http://www.wsmi.org/.

8. Puspita VM. Faktor-faktor yang mempengaruhi pengambilan keputusan keluarga dalam pengobatan sendiri (selfmedication) di Kabupaten Sleman, DIY. [Skripsi]. In press 2008.

9. Supardi S, Soedibyo J, Loupatty AM. Beberapa faktor yang berhubungan dengan penggunaan obat tradisional dalam pengobatan sendiri di Indonesia. Bul Penel Kesehatan. 2003;31(1):25-32.

10. Friedman MM. Keperawatan keluarga: teori dan praktik. Jakarta: EGC; 1998.

11. Kristina SA, Prabandari YS, R S. Perilaku pengobatan sendiri yang rasional pada masyarakat Kecamatan Depok dan Cangkringan Kabupaten Sleman. Majalah Farmasi Indonesia. 2008;19(1):32-40.

12. Supardi S, Sukasediati N, Azis S. Pola penggunaan obat dan obat tradisional dalam upaya pengobatan sendiri di tanjung bintang, lampung. Bul Penel Kesehatan. 1997;25(3) 